how historians choose to define them, cannot always be counted upon to demonstrate moral righteousness. But to make a claim for the legitimacy or appropriateness of the Vichy Labor Charter based on the fact that members of the anticapitalist hairdresser's union supported it neglects the fact that other "workers" equally unhappy with the capitalist system, such as the railway workers, actively resisted the regime. Zdatny might have done hairdressers and workers more justice by investigating the aesthetics of fascist hairstyles rather than he did by drawing the conclusion that "workers" could find some aspects of Vichy Labor law redeeming. If historians begin to break down the category "working class," they are sure to find, especially in the context of World War Two, that what was "good" for some workers was not necessarily good for all.

\title{
For Us There Are No Frontiers: Global Approaches \\ to the Study of Italian Migration and the Making of Multiethnic Societies, 1800 to the Present
}

\author{
Michael Miller Topp \\ University of Texas at El Paso \\ Roberto Ventresca \\ University of Toronto
}

In early April 1996, nineteen scholars from seven countries met at L'Unione Italiana (the Italian Club) in Tampa, Florida, to examine the impact of Italian migration worldwide in roughly the last two centuries, not only on the countries to which these migrants went, but on Italy as well. The study of this migrant population is a massive undertaking, as the breadth of the papers showed: Between 1800 and 1970, twenty-six million Italians migrated within Europe or across oceans in search of work. Chronologically the papers extended from a piece by conference organizer Donna Gabaccia (University of North Carolina at Charlotte) on migration before and especially during the Risorgimento to work by Roberto Ventresca (University of Toronto) on the effect of the historical memory of Italo-Canadians' sympathy with and support for Fascism and Mussolini on the politics of ethnic identity in that community in the present day. Geographically, the papers presented explored Italian migration to other European countries, to South America and Central America, to Canada and the United States. 
In the papers they presented and especially in the vigorous discussions that followed them, the participants sought several ends: to examine the reception of and participation by Italian workers in the labor movements and polities of the countries to which they migrated; to question and problematize the exceptionalism of any individual nation's history by examining its class, racial, and ethnic dynamics in comparative perspective; and to reintegrate the study of Italian migration into Italian history.

Inspired by the work of Ernesto Ragionieri, who over thirty years ago urged scholars to examine the impact of Italian circular migration on labor movements both in Italy and abroad, Donna Gabaccia examined political migrants before and during the Risorgimento - between 1790 and 1871 - as conveyors of political ideas both out of and into Italy. These migrants brought ideas about and arguments for the reunification of Italy into diaspora communities of fellow Italian migrants. Their capacity to spread these ideas was limited by several factors. They tended to remain in countries close to Italy, because they didn't want to lose their influence on events in their home country. As a group they also tended to be overwhelmingly male, and thus their potential impact on the diaspora communities was limited because their kinship ties-which bound them more closely to a community - tended to be in Italy rather than in the migrant communities. Nonetheless, Gabaccia argued, within these limitations they were able to act as conduits for Risorgimento ideas outside Italy. These political migrants also carried debates conducted in such places as London, Buenos Aires, Paris, and Alexandria back into Italy. As a rule more radical than the Risorgimento activists who remained in Italy, they returned to their native country with, for example, reinforced and broadened ideas about republicanism and representative government.

Conference participants focused not only on the conveyance of ideas into and out of Italy, but also on the impact of Italian migrant radicals both on their fellow migrants and on the labor movements in the countries to which they moved. Elisabetta Vezzosi (Università di Bergamo) focused on the role of Italian migrant social democrats as "radical ethnic brokers" between Italian migrants and the larger society in the United States in the first decades of the twentieth century. Arguing that not every mediator between the two cultures was a padrone or an exploiter of Italian workers, Vezzosi pointed out that these social democrats could and did function as agents of assimilation and Americanization as they themselves became more firmly entrenched in the United States culturally and politically. Vezzosi's paper broke down the distinction, which she argued has been drawn too sharply by John Higham, between leaders of protest and leaders of accommodation in immigrant communities. Italian social democrats often functioned in both roles at the same time, utilizing the labor movement and the Socialist party as entryways for themselves and for Italian migrant workers generally into American society.

A paper by Carina Silberstein (Universidad Nacional de Rosario) 
focused on Italian migrants as part of a heterogeneous rural labor force in Argentina composed of peasant farm hands, native seasonal workers, and (often Italian) sojourner laborers, and on the tension within the Italian migrant community produced by the labor protests that erupted at the beginning of the 1910s. Labor strikes in these years compelled Italian migrants to confront the impossibility of cooperation and ethnic solidarity in a community in which the economic elite faced the complaints of fellow migrants who were working for them as farmers and who were organized and backed by Italian migrant radicals. The labor protests also evoked debate on broader issues of ethnic identity. Especially in the Federación Agraria Argentina (FAA), the major association organizing Italian migrant rural workers, the debate focused on the level of integration into Argentinian society necessary to achieve their ends: whether to naturalize, to what extent to fight to preserve a sense of Italian identity. The idea of naturalizing was not a popular one in the years before World War One, Silberstein argued, but, pushed by the FAA, gained momentum in the years after the war.

The papers on the final day of the conference were devoted entirely to examining the struggle of antifascists to combat the popularity of Mussolini's Fascism in migrant communities in Europe and in North, South, and Central America. In the process, as conference organizer Fraser Ottanelli (University of South Florida) argued, Italian migrant antifascists sought to reconcile the tensions between their identity as Italians and their participation in the labor movement in the United States. Whereas Italian migrant radicals tended to organize their fellow migrants into separate ethnically based organizations in the years before World War One, Ottanelli argued that in the interwar years as a rule they tended to seek inclusion in multiethnic militant labor organizations and political parties. This did not mean that their connections to Italy were severed; indeed, their participation in these multiethnic organizations, their Italian national identity, and their increasing commitment to life outside of Italy could at times be mutually reinforcing. For example, Italian migrant antifascists, often members of "new unions" like the International Ladies Garment Workers Union or the Amalgamated Clothing Workers of America, opposed the Fascists' arguments that in supporting Mussolini Italians abroad could both regain pride in their home country and remain in step with American ideals. The antifascists countered that opposing Mussolini made their fellow migrants both Italian "patriots" and "true" Americans.

Pietro Rinaldo Fanesi (Istituto regionale per la storia del movimento de liberazione nelle Marche) approached the subject of Italian antifascists in Latin America by reference to a specific theme-namely, the struggle between Italian antifascists (in countries like Argentina, Uruguay, and Brazil) and Fascist officials in Italy over the myth of Garibaldi and the use of Garibaldian tradition. In the 1920 s and 1930s, Fascists and antifascists alike claimed Garibaldi as one of their own, the Fascists on the grounds of his 
anticlericalism and nationalism, the antifascists on the grounds of his internationalism, anti-imperialism, and humanitarian socialism. This struggle came to a head in the 1930s, argued Fanesi, and especially in 1932-the fiftieth anniversary of Garibaldi's death - when antifascists in Latin America launched a vigorous campaign to counter the "official" Fascist commemoration in Italy itself. In opposing this commemoration, Italian antifascists in Latin America were attempting to exploit the "myth" of Garibaldi for the first time for their own ideological purposes. Thus 1932, Fanesi argued, marked a turning point in the antifascist campaign in Latin America, away from the "defensive" posture of the 1920s and toward a spirit of reconquest. Under a Garibaldian banner, Fanesi suggested, and provoked by the Italian invasion of Ethiopia and later the Spanish Civil War, the disparate elements of Italian antifascism in Latin America were finally unified.

The Italian Club in Tampa was an ideal setting for the conference. Not only does the building itself have a rich history-the Italian immigrant organization that built it was founded in 1894-but the city itself has been home to a large and diverse immigrant population for much of its history. Throughout the meeting, Ottanelli and Gabaccia strove to integrate events with popular appeal into the proceedings. The first evening, Dirk Hoerder (Universität Bremen) and Gary Mormino (University of South Florida) moderated a panel composed of Italian, Spanish, and Cuban immigrants reflecting on the history of radicalism in Tampa. The second night featured readings from Denis Calandra's Cuban Bread, a play based on a 1931 strike waged in Ybor City and West Tampa, followed by commentary from Carina Silberstein and Nancy Green (École des Hautes Études en Sciences Sociales, Paris). Both nights' events were open to the public and complemented the more scholarly proceedings of the conference very well.

\title{
Eighty-Ninth Annual Meeting of the Organization
}

\author{
of American Historians
}

\author{
Greg Kaster \\ Gustavus Adolphus College \\ R. Todd Shuman \\ University of Illinois at Urbana-Champaign
}

"History, Memory, and Identity" was the focus of the 1996 conference of the Organization of American Historians (OAH), held in Chicago from March 28 to March 31. Together, the several panels and individual papers 